\title{
MODEL PEMBELAJARAN KOOPERATIF TIPE NHT DALAM ANALISIS KESALAHAN BERBAHASA INDONESIA PADA MAHASISWA PBI UNIPA SURABAYA
}

\author{
Sri Budi Astuti ${ }^{1)}$ dan Ira Eko Retnosari ${ }^{2)}$ \\ ${ }^{1,2}$ Fakultas Keguruan dan Ilmu Pendidikan Universitas PGRI Adi Buana Surabaya \\ Email: ${ }^{1}$ sri.budi@unipasby.ac.id, ira@unipasby.ac.id ${ }^{2}$
}

\begin{abstract}
Abstrak
Fenomena yang sering ditemukan pada mahasiswa adalah terjadinya kesalahan bahasa saat berkomunikasi. Hal ini pula terjadi pada mahasiswa program studi pendidikan bahasa Indonesia (PBI). Adapun jenis-jenis kesalahan dalam berbahasa meliputi fonologi, morfologi, sintaksis, dan semantik. Untuk mengurangi atau meminimalisir terjadinya kesalahan berbahasa dosen menggunakan model number head together (NHT). Melalui model tersebut, penelitian ini mengembangkan suatu produk yaitu modul "Analisis Kesalahan Berbahasa Indonesia". Jenis data yang digunakan terdapat 3 (tiga) di antaranya: deskriptif, kualitatif, dan kuantitatif. Prosedur penlitian digunakan langkah 4D: define, design, development, dan dissemination. Dari penelitian ini, dihasilkan bahwa proses pembuatan modul Anakes Ber-BI sudah sesuai dengan prosedur pengembangan dari Thiagarajan yang secara umum disebut model 4D. Kualitas modul Anakes Ber-BI dilihat berdasarkan segi kelayakan isi, kebahasaan, sajian mendapatkan validasi kelayakan dengan kriteria baik”. Kualitas modul Anakes Ber-BI ditinjau dari aspek kelayakan kegrafikan mendapatkan validasi kelayakan dengan kriteria "baik". Dengan dihasilkannya produk berupa modul Anakes Ber-BI, dosen dapat mengembangkan modul dengan tipe NHT dalam mata kuliah Anakes ber-BI dan mahasiswa dapat menganalisis kesalahan berbahasa Indonesia.
\end{abstract}

Kata kunci: Analisis Kesalahan Berbahasa Indonesia, 4D, NHT, Modul Anakes Bebahasa Indonesia.

\begin{abstract}
The phenomenon that is often found in students is the occurrence of language errors when communicating. This also happened to students of the Indonesian Language Education Study Program (PBI) in 2016. The language errors included phonology, morphology, syntax, and semantics. To reduce or minimize the occurrence of language errors lecturers use the number head together (NHT) model. Through the NHT model, this research develops a product called the "Indonesian Language Error Analysis" module. There are 3 (three) types of data used: descriptive, qualitative and quantitative. The research procedure used in step 4D: define, design, development, and dissemination. The results of this study indicate that the process of making the BI-Anakes module is in accordance with the development procedures of Thiagarajan, known as the Four-D Models (Model 4D). The quality of the BI-Anakes module is evaluated from the aspect of content eligibility, language eligibility, and the feasibility of the presentation to obtain validity with good criteria ". The quality of the BI-
\end{abstract}


Anakes module is evaluated from the aspect of the feasibility of obtaining a validation of eligibility with "good" criteria. With the production of products in the form of the BI-Anakes module, lecturers can develop modules with the NHT type in the BI-Anakes course and students can analyze Indonesian language errors.

Keywords: Indonesian Language Error Analysis, 4D, NHT, Error Analysis Module in Indonesian

\section{Language}

\section{PENDAHULUAN}

Salah satu fenomena yang terjadi pada mahasiswa di perguruan tinggi adalah mahasiswa cenderung kurang tepat dalam penggunaan tata bahasa. Kesalahan penggunaan tata bahasa yang dialami oleh mahasiswa meliputi fonologi, morfologi, sintaksis, dan semantik. Ironisnya, kesalahan penggunaan bahasa tersebut ditemukan pada mahasiswa PBI 2016. Kesalahan penggunaan tata bahasa disebabkan oleh penggunaan interferensi pada mahasiswa tersebut. Chaer (2007:66) menjelaskan bahwa terjadinya interferensi pada tataran bahasa mencakup fonologi, morfologi, sintaksis, sampai ke tataran leksikon.

Kesalahan-kelasahan penggunanaan tata bahasa pada mahasiswa contohnya sebagai berikut. Pertama, dilihat dari fonologi misalnya fonem $n$ dan $m$ pada kata Bandung menjadi Mbandung. Kedua, dilihat dari morfologi pada imbuhan in di belakang kata seperti ambilkan menjadi ambilin. Ketiga, dilihat dari sintaksis pada kalimat berikut Pada penelitian ini menggunakan metode kualitatif. Kata pada di awal subjek kalimat aktif akan mebuat subjek rancu kalimat tersebut. Keempat, dilihat dari semantik pada kata pukul dan jam seperti kalimat berikut Saya berangkat dari Surabaya ke Malang dari pukul 07.00 sampai 09.00. Kalimat tersebut terdapat kesalahan yang diakibatkan kata pukul seharusnya jam karena menunjukkan rentang waktu..

Berkaitan dengan fenomena yang ada, diperlukan model pembelajaran yang sesuai untuk mahasiswa PBI 2016 yaitu model NHT. Tujuan dalam penelitian ini yaitu melalui model NHT dapat membuat mahasiswa PBI 2016 dalam keterampilan berbicara lebih baik.

Dari uraian di atas, Suprijono (2015:111) menjelaskan model NHT digunakan dalam pembelajaran dimulai dengan numbering. Menurut Lie (2008:59) dalam Suprijono (2015:111) menjelaskan model NHT yang dilakukan dengan cara berkelompok dan diberikan kesempatan pada siswa agar berbagi ide-ide dengan pertimbangan paling sesuai jawabannya selama menyelesaikan tahap-tahap pembelajaran.

Dengan demikian, melalui model NHT dalam mata kuliah analisis kesalahan berbahasa Indonesia, dosen membantu mahasiswa agar tujuan dalam pembelajaran dapat tercapai. NHT diharapkan lebih menyenangkan dan dapat membantu kesulitan mahasiswa dalam 
memperoleh ide ketika penggunaan berbahasa di dalam kelas.

Selain model NHT, digunakan modul sebagai media untuk pembelajaran analisis kesalahan berbabahasa Indonesia. Modul tersebut sebagai media pembelajaran berciri: (a) bersifat self-instructional artinya modul diajarkan dengan menggunakan konsep pembelajaran; (b) Perbedaan secara individual diakui artinya bahwa perbedaan secara individual pembelajaran dengan modul dianggap tepat untuk menanggapi mahasiswa.

Hal ini disebabkan pada hakikatnya modul disusun agar mahasiswa dapat menyelesaikan modul itu secara individu; (c) secara eksplisit, dimuat rumusan tujuan pembelajaran/kompetensi dasar; (d) berkaitan dengan asosiasi artinya mahasiswa dengan proses asosiasi terjadi karena dengan membaca teks dan melihat diagram dalam modul. Struktur dan urutan berarti materi dalam modul itu dapat dibuat dengan bentuk konsep secara hierarkis; (e) Pemakaian jenis-jenis multimedia maksudnya modul dapat digunakan dalam pembelajaran dengan pelbagai media; (f) mahasiswa dapat secara aktif berpartisipasi maksudnya materi dalam modul bersifat self instructional. Dengan demikian, mahasiswa lebih aktif belajar; (g) reinforcement respon mahasiswa maksudnya mahasiswa mendapatkan jawaban yang tepat dan koreksi berdasarkan kesalahannya, (h) evaluasi hasil belajar mahasiswa menunjukkan tingkat kemampuan mahasiswa dalam mempelajari materi.

\section{METODE PENELITIAN}

Jenis penelitian pengembangan ini adalah mengembangkan suatu produk. Adapun produk tersebut berupa modul "Analisis Kesalahan Berbahasa Indonesia".

Melalui modul tersebut, digunakan NHT. NHT adalah variasi belajar berkelompok untuk menguatkan setiap mahasiswa lebih memahami materi dalam kelompok tersebut.

Pengumpulan data dalam penelitian ini ada tiga. Pertama, proses pengembangan modul "Analisis Kesalahan Berbahasa Indonesia" berdasar tahap-tahap pengembangan yang ada. Kedua, kesesuaian materi dan media modul "Analisis Kesalahan Berbahasa Indonesia". Data tersebut mencakup: data kualitatif dan kuatitatif. Tiap-tiap nilai dalam kriteria penilaian dapat dijelaskan berdasarkan skala sangat baik (SB), baik (B), kurang (K), dan sangat kurang (SK). Hal tersebut sebagai data kualitatif. Sedangkan, data kuantitatif ditunjukkan dengan skala penilaian ( $\mathrm{SB}=4, \mathrm{~B}=\mathrm{K}$, kurang $=2$, $\mathrm{SK}=$ 1). Selanjutnya, diolah berdasarkan rumus: $\bar{X}=\frac{\sum x}{n}$ dan dengan menghitung mean dari penilaian setiap kriteria dari ahli materi dan media.

lembar validasi kelayakan dari ahli materi dan media digunakan sebagai instrumen. Untuk menemukan alur penelitian, digunakan langkah 4D. Thiagarajan (1974:5) berpendapat terdapat empat langkah 4D. Keempat langkah, masing-masing dipaparkan di bawah ini.

1. Pendefinisian (define)

Pendefinisian adalah aktivitas menganalisis kurikulum, analisis kebutuhan, dan ciri khusus mahasiswa. 
2. Perancangan (design).

Aktivitas perancangan desain mencakup:

a. Memilih konten materi

Materi dikembangkan berkaitan dengan analisis kurikulum dan kebutuhan mahasiswa. Setelah itu, disusun inti materi untuk perkuliahan.

b. Mendesain modul

Aktivitas ini dilakukan dengan mendesain modul "AnakesBer-BI". Hal tersebut dilakukan agar modul tampak lebih baik dan mudah dicerna.

3. Pengembangan (development)

Aktivitas ini dilakukan dengan mengolaborasikan isi dan desain. Penyusunan modul "Anakes Ber-BI", peneliti selalu melakukan revisi. Setelah modul "Anakes Ber-BI" dinyatakan layak untuk divalidasi, selanjutnya modul divalidasi oleh ahli materi dan ahli media untuk mendapatkan kelayakan digunakan dalam pembelajaran.

Perolehan data digunakan dengan teknik lembar validasi kelayakan yang dilihat dari segi kelayakan isi, kebahasaan, dan sajian. Analisis data digunakan teknik kualitatif, deskriptif, dan kuantitatif.

\section{HASIL DAN PEMBAHASAN}

Menurut Setyawati (2010:15), pemakaian bahasa baik secara lisan maupun tertulis yang terdapat kesalahan dari segi penyimpangan norma masyarakat dan kaidah tata bahasa Indonesia. Berbeda dengan Setyawati, Corder (1974) memakai tiga istilah dalam kesalahan berbahasa meliputi (1) lapses, (2) error, dan (3) mistake.

Penggunaan bahasa yang menimbulkan kesalahan dapat diminimalisasi dengan model NHT. Huda (2012:130) menjelaskankan bahwa NHT adalah salah satu variasi belajar kelompok, dengan cara penerapannya mirip diskusi kelompok. Dengan model NHT, peningkatan keaktifan belajar semakin baik dan menumbuhkan sikap saling menolong pada pelbagai tingkah laku sosial.

Kemudian, digunakan pula sebuah produk berupa modul "Analisis Kesalahan Berbahasa Indonesia". Buku ajar atau modul merupakan sejenis buku yang dapat dipakai dalam proses belajar mengajar (Arifin, 2008:57).

Berikut akan disajikan hasil data deskriptif, kualitatif, dan kuantitaif.

\section{A. Data deskriptif}

Secara rinci, penjelasan hasil penelitian ini yang diperoleh dari penjabarannya berpedoman pada langkah 4D, yakni tahap pendefinisian, tahap perancangan, tahap pengembangan. Berikut penjelasan keempat tahap tersebut.

1. Tahap Pendefinisian

Dalam upaya mengembangkan buku, perlu dilakukuan definisi analisis pada berberapa aspek, yaitu:

a. Anakes ber-BI sesuai dengan kurikulum KKNI.

b. Analisis kebutuhan dan karakteristik mahasiswa.

2. Tahap Perancangan

Berdasarkan data, tahap perancangan seperti di bawah ini.

a. Memilih isi materi yang akan dikembangkan 
Modul tentang analisis kesalahan berbahasa Indonesiakan digunakan sebagai referensi. Perancangan dimulai dengan mendokumentasikan dan menentukan kiat-kiat yang menarik dari bermacam-macam literatur.

b. Menyusun desain modul

Perancangan desain modul yang berbentuk modul dan menentukan komponen yang terdapat pada modul seperti berikut.

1) Pendahuluan, terdiri atas: a) halaman sampul, b) halaman motivasi, c) kata pengantar, d) daftar isi;

2) Isi, meliputi: a) materi, b) perlatihan;

3) Penutup, mencakup: a) daftar pustaka;

c. Tahap Pengembangan

Tahap pengembangan adalah tindak lanjut dari tahap desain, mencakup penyusunan dan pengetikan secara menyeluruh materi dan rancangan yang telah ditentukan. Selama tahap pengembangan modul tentang analisis kesalahan berbahasa Indonesia dilakukan revisi, baik dari dari dosen ahli. Setelah modul tentang analisis kesalahan berbahasa Indonesia layak dilakukan validasi, modul divalidasi oleh ahli materi dan media.

a. Penyajian data kualitatif

Pembuatan lembar validasi kelayakan berdasarkan hasil identifikasi pembuatan buku. Pada lembar validasi, tertulis pilihan respon validator yakni nilai tiap kriteria penilaian $\mathrm{SB}=4, \mathrm{~B}=3, \mathrm{~KB}=2$, $\mathrm{SKB}=1$ )

b. Penyajian data kuantitatif
Berikut disajikan data tentang
validasi kelayakan isi, kelayakan kebahasaan, dan kelayakan sajian modul tentang analisis kesalahan berbahasa Indonesia oleh ahli materi.

Berdasarkan hasil analisis data, dapat dijelaskan bahwa rerata nilai yang diberikan validator 1 yaitu angka 4 . Begitupun juga dengan validator 2 rerata yang diberikan yaitu angka 4. Artinya, validator satu dan dua memberikan nilai angka 4 dengan konversi nilai sangat baik.

Selanjutnya, hasil saran validasi kelayakan isi, kelayakan kebahasaan, dan kelayakan sajian modul "Anakes Ber-BI" ahli materi.

Modul ini menyajikan materi yang smart, konsisten, dan dinamis yang mudah dipelajari mahasiswa. Kelebihan modul ini adalah rangkuman materi terutama anakes BI dapat dijadikan pedoman, solusi permasalahan tiap materi disajikan secara lengkap, dan (3) mahasiswa lebih memahami isi modul karena kalimat dalam modul mudah dipahami, dan (4) penyajian contoh kesalahan ber-BI dapat lebih membantu mahasiswa dalam menganalisis kesalahan ber-BI.

\section{B. Analisis Data}

Dalam analisis data, dijelaskan hasil validasi kelayakan pengembangan dari segi kelayakan isi, penyajian, dan kebahasaan. Hasil penilaian aspek kelayakan isi menunjukkan nilai rata-rata 3.9 dengan konversi SB, kelayakan penyajian mendapatkan nilai rerata 3.8 dengan konversi SB, kelayakan kebahasaan nilai rerata nilai 3.9 dengan konversi SB. Dari 
penilaian ketiga aspek tersebut, ditunjukkan SB.

\section{Pembahasan}

Penelitian pengembangan ini berpedoman pada model pengembangan 4D yang dimodifikasi yang terdiri atas empat tahap yaitu tahap pendefinisian, tahap perancangan, tahap pengembangan.

Dari hasil validasi kelayakan modul "Anakes Ber-BI", diperoleh hasil kriteria secara keseluruhan, baik dilihat dari segi kelayakan isi, penyajian, maupun kebahasaan bahwa modul ini sangat baik.

\section{KESIMPULAN}

Dari hasil analisis data dan pembahasan penelitian pengembangan berjudul Model Pembelajaran Kooperatif Tipe NHT dalam Analisis Kesalahan Berbahasa Indonesia pada Mahasiswa PBI Unipa Surabaya, dapat disimpulkan bahwa proses pembuatan modul Anakes Ber-BI sesuai dengan prosedur pengembangan Model 4D. Kualitas produk modul Anakes Ber-BI dengan ketiga aspek kelayakan yang mencakup kelayakan isi, penyajian, dan kelayakan kebahasaan menunjukkan kriteria sangat baik.

\section{UCAPAN TERIMA KASIH}

Ucapan terima kasih disampaikan kepada semua pihak yang telah membantu dalam penyelesaian penelitian ini. Adapun pihak-pihak tersebut adalah (1) Drs. Djoko Adi Walujo, S.T., M.M., DBA., selaku Rektor Univesitas PGRI Adi Buana Surabaya atas kebijakannya yang telah mendanai penelitian ini, (2) Dr. Suhari., M.Si., selaku Dekan FKIP Universitas PGRI Adi Buana Surabaya atas kebijakannya yang telah memfasilitasi sehingga penelitian ini dapat terselesaikan, (3) Dr. Sukarjati, M.Kes., selaku Ketua Lembaga Penelitian dan Pengabdian Masyarakat Universitas PGRI Adi Buana Surabaya, yang telah banyak membantu dan memberi saran serta memberi motivasi sehingga penulisan laporan penelitian inni dapat terselesaikan tepat waktu, (3) Dr. Sunu Catur Budiyono., M.Hum., selaku Kaprodi Pendidikan Bahasa dan Sastra Indonesia yang telah memberikan motivasi untuk selalu meningkatkan kemampuan meneliti, (4) Teman-teman seprofesi yang telah banyak memberikan saran dan motivasi, dan (5) Pihak-pihak yang tidak bisa saya sebutkan, yang telah membantu terselesaikannya penelitian ini sampai pada pemublikasiannya.

\section{REFERENSI}

Arifin, E. Zaenal dan S. Amran Tasai. 2008. Cermat Berbahasa Indonesia untuk Perguruan Tinggi. Jakarta : Akademika Pressindo.

Chaer, Abdul. 2007. Linguistik Umum. Jakarta: Rineka Cipta.

Huda, Miftahul. 2012. Cooperative Learning Metode, Teknik, Struktur, dan Model Terapan. Yogyakarta: Pustaka Pelajar.

Setyawati, N. 2013. Analisis Kesalahan Berbahasa Indonesia. Surakarta: Yuma Pustaka.

Suprijono, Agus. 2015. Cooperative Learning. Yogyakarta: Pustaka Belajar 